\title{
DEVELOPING E-SCATTERGORIES GAME IN WRITING DESCRIPTIVE TEXT FOR THE TENTH GRADE IN VOCATIONAL SCHOOL
}

\author{
AN ARTICLE
}

Submitted in Partial Fulfillment of the Requirements for the Degree of Sarjana Pendidikan

By:

JULITA ENNIS

Registration Number: 2163121031

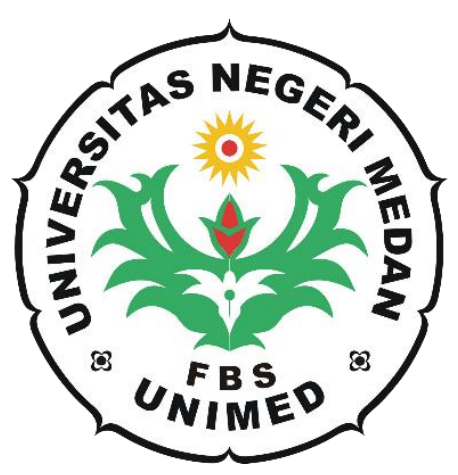

ENGLISH AND LITERATURE DEPARTMENT

FACULTY OF LANGUAGES AND ARTS

STATE UNIVERSITY OF MEDAN

2021 


\title{
DEVELOPING E-SCATTERGORIES GAME IN WRITING DESCRIPTIVE TEXT FOR THE TENTH GRADE IN VOCATIONAL SCHOOL
}

\author{
*Julita Ennis
}

**Dr. Rahmad Husein, M.Ed

\begin{abstract}
Ennis, Julita. 2163121031. Developing E-Scattergories Game in Writing Descriptive Text for The Tenth Grade in Vocational School. A Thesis, English Educational Program, Faculty of Languages and Arts, State University of Medan, 2021.

The objective of this study is to develop E-Scattergories game as a media to teach writing descriptive text for the tenth grade students in SMK Namira Tech Nusantara Medan. This study was conducted by using Research and Development design through six stages; gathering data and information, need analysis, designing materials and media, validating, revising, get the product. The subject of the study was tenth grade students and the English teacher in SMK Namira Tech Nusantara Medan. The data were gathered by reviewing documents, conducting interview to English teacher and distributing questionnaires to TKJ 1 (Teknik Komputer Jaringan) consisting of 18 students to get the students' need. The interview and questionnaire results proved that the students to neededdigital game as a media. The developed writing materials were validated by two experts with the average scores of 92.66 of 100 . It shows that the E-Scattergories game is valid and suitable to be used for the tenth grade students in SMK Namira Tech Nusantara Medan. The final product can be used from EScattergories developer.egoarchitect.com.
\end{abstract}

Key words: development, E-Scattergories game, digital game, descriptive text.

\footnotetext{
*Graduate Status

** Lecturer Status
} 


\section{INTRODUCTION}

\section{Background of Study}

Writing has a unique position in language teaching since its acquisition involves a practice and knowledge of other three language skills, such as listening, reading and speaking. By learning how to write, the students will get the chance to share their ideas and express their thoughts with everyone through writing. Harmer (2004: 31-33) states that writing has some importances, such as writing encourages students to focus on accurate language use because they think as they write, writing has always been used as a means to reinforcing language that has been taught, writing is also used to help students perform a different kind of activity (speaking and listening). In the curriculum, the English material in vocational school is also taught based on the text. One of the texts that has to be learned by the students of vocational high school is a descriptive text.

Based on the standard competence in the syllabus of the first year students of vocational high school called 2013 Curriculum, students are expected to be able to write simple paragraphs of recount, narration, and description. It is said that students have to be able to write various types of genre texts, one of them is descriptive text. Descriptive text is usually focused on writing appeals to the senses, so it tells how something looks, feels, smells, tastes, and/or sounds. According to Suryana (2008), descriptive text also used to create image of the people, place, even of units, times of the day, or seasons. 
Writing is still considered difficult since its objectives are not easy to be achieved. Most of the students' skills are far away from their learning targets. That is because of many problems. In preliminary observation, researcher found many problems in English learning process at Yayasan Fajar Islam Sekolah Namira Medan. Based on the interview with the teacher that has conducted on Wednesday, 24 June 2020 at 10.30 a.m, he said that learners faced many problems in English learning, especially in writing. The problem found is often about difficulties in finding the interesting and creative media or ways to make the students interested and enjoy in writing. As a result, in teaching English, the teacher just focused on the student's worksheet and giving the students several tasks. In the meantime, teacher also presents pictures and powerpoint in teaching descriptive text. The researcher also found that online media is rarely used in teaching and learning process, especially using digital game in learning process. Whereas, the school is facilitated by internet connectivity and computer laboratory. These problem are likely to contribute the students' low motivation and how to write well and make them confused and bored in writing class.

To consider the importance of descriptive text for the students to be mastered, it is very important for the teacher to creatively apply ways of teach a descriptive text in order to achieve the objectives that are stated in the curriculum. In traditional classrooms, teachers stand in front of learners and give lesson, explanation, and instruction through using blackboard or whiteboard. As explained by Prensky (2006: 27) states that today's students have spent their entire lives surrounded by and using computers, video games, DVD players, videocams, eBay, cell phones, iPods, and all 
the other toys and tools of the digital age, students have been familiarised themselves with English, because almost all instructions of the toys and tools of the digital age are in English. As a result, what teachers need to do is improvise their ways of teaching by incorporating students' interests in their method. The usage of a variety of teaching aids has effectively transformed most classrooms from traditional setup. For that, the use of various teaching media is necessary for motivating students to learn English.

By mastering a good teaching media, the teacher will be able to perform well in the teaching learning process and simultaneously to achieve the targets. Existing media can also be used to engage students and facilitate active learning strategies which promote deeper learning. For example, media provides a useful platform for teaching with cases, cooperative learning, problem solving, and for giving more interactive lecture demonstrations.

There are some kinds of media that can be used in the teaching and learning process. However, every medium has different effects depending on the students' need. That is why, we should search and develop effective media in teaching in order to promote students' English skill. 1) In the modern era, the development of teaching media increases rapidly. 2) Teaching using technology in the classroom setting can assist students' learning. 3) However, it can be challenging for the teachers to select the best technology tool while not losing the essence goals for students learning. 4) Teaching and learning by using online media is one way to get closer to ICT (information Communication and technology). 
Students' digital world can be an effective way to make English learning more alive. Not only because technology has been a part of students' everyday lives, but also because it offers many ways to develop students' skills to compete in the 21 st century. One of digital media to help students in writing descriptive text is game.

According to Sigurdardottir (2010: 7-9) there are other reasons why games are really suitable to be applied to promote fun learning in language, especially in learning writing. The researcher decides to develop E-Scattergories Game in writing descriptive text for students in vocational school because this is one of creative digital media which can be used by the teacher to stimulate the students to develop their idea in writing descriptive text. Originally, scattergories game is appropriate to use for upper-intermediate level students and effective for building groups of similar vocabulary. Players have a time limit and they have to think of words which are suitable for particular categories.

E-Scattergories game is a board game that originally uses paper, as well as other tools to be played together in a group. To make English learning more alive, not only because technology has been a part of students' everyday lives, but also because it offers many ways to develop students' skills to compete in the 21 st century. Researchers develop Scattergories Game in digital version as an innovation to support the students in learning writing. Researchers hope with this digital game, the teacher is more practical to motivate students in the process of introducing descriptive text. This game not only providing the students to increasing the mood, solving or enriching the lack of vocabularies in writing, but also stimulating them to think fast and can get the ideas in writing descriptive text. 


\section{REVIEW OF RELATED LITERATURE}

\section{Theoretical Framework}

Harmer (2004:31) states that writing (as one of the four skills of listening, speaking, reading, and writing) has always formed parts of the syllabus in the teaching of English. The importance given to writing differs from teaching situation to teaching situation. Writing for writing role where the students write predominantly to augment their learning the grammar and vocabulary of the language.

Many people consider that writing is one of the most complicated language skills. Richards \& Renandya (2002: 303) state that writing is the most difficult skill to master because of its difficulties in generating, organizing, and translating ideas into a readable text. When writing a composition, we should think about language aspects for composing a final writing. To make the writing process runs smoothly, some indicators in writing skill must be mastered by a writer.

In accordance with Richard \& Renandya (2002: 303), Talak-Kiryk (2010:4) states that games are fun activities that promote interaction, thinking, learning, and problem solving strategies. Often, games have an aspect that permits the players to produce information in a short period. Some games also require the players to engage in a physical activity and/or complete a mental challenge.

The statement above explains why games can be one of the best alternatives for teaching a certain skill in a classroom setting. The use of game does not only 
reinforce the use of language, but also stimulate creativity, independence thinking, and collaboration among the members of the class.

Media can be effectively used in a formal situation where students are working independently or the teacher is working with another group of students. Media plays a significant role in the education of students with exceptionalities children with disabilities in particular need special instructional treatment which is supplemented with adaptation and specially designed media for effective instruction of such students. The most common use of media in an instructional situation is for supplemental support of the instructor in the classroom to enhance learning.

Teaching aids certainly amplify the teacher's effortful presentation more into influencing instructions. Thomas (2008:106) explains that teacher who uses a variety of teaching aids has successfully converted most classrooms from traditional setup, where teachers do most of the talking and students are passive listeners, into participatory learning centers facilitating productive learning.

\section{Conceptual Framework}

Writing as one of four important skills (listening, speaking, reading, and writing) in learning English, have to be mastered by students because writing can help them to think critically and deeply. By learning writing, the students will get the chance to share their idea and express their thoughts with everyone through a written text. In regard with this statement, writing is one of English skills which is very important in daily life. In order to get benefit of an effective teaching writing process, 
the teacher not only has to prepare good materials but also teaching media as well. If properly designed, skillfully produced and effectively used, the media have a great influence on teaching and learning.

To make the learning experiences of the learners more concrete and realistic in learning descriptive text, teachers have to use and prepare specific teaching materials. In descriptive text, students used to describe particular thing, person, animal, place and or event to the readers or hearers. The process of describing is done through ordering their characteristics clearly, starting from naming them, classifying them, and dealing with their attributes, behaviors, and functions.

To help the students in mastery the material, teacher can use game as one of media in teaching descriptive text. The game that can be used by teacher is $e$ scattergories game. This game is one of the interesting media for students to be used in teaching and learning process to give an idea to write a descriptive text.

The materials and the media must be evaluated by the material and media experts to know their appropriateness. Then, the media and materials are tried out with students to know whether they are suitable or not. Besides conducting tryout, the researcher conducts the evaluation by giving questionnaires to get the feedback from the students and the English teacher. Finally, the result of the expert judgment, the answers from the students and the English teacher are used to revise the media and the materials.

\section{RESEARCH METHODOLOGY}


This research was conducted by using research and development (R\&D) method by Borg and Gall. Borg and Gall (2003) state that R \& D is one of research designs that used as the method to develop and validate some educational products such as curriculum, syllabus, textbooks, instructional media, modules, assessment, and instrument.

In this research used interview guide and questionnaire to collect the data. Therefore, researcher got the data source from one English teacher and students in the tenth grade students of computer and network engineering major at SMK Namira Tech Nusantara Medan .

\section{Techniques of Analysis Data}

\section{Gathering data and Information}

The data and information were collected from the preliminary observation done before doing the research. From the data, it was found that the English teacher in tenth grade of SMK Namira Tech Nusantara Medan just focused on the student's worksheet and giving the students several tasks.

\section{Need Analysis}

In conducting this research, the second step needed to be completed was doing the need analysis. The need analysis was done by giving the grade tenth students questionnaire and were asked to answer some questions. This analysis of the students' needs later become the guidance to the researcher in developing the media of writing descriptive text. 
a. Questionnaire Analysis. There are categories need to be covered, namely lacks, necessities and wants. The three categorize presented in which questions number 1-4 about lacks, the questions number 5-11 about necessities and the questions number 12-15 about wants.

b. Interview Analysis. It was conducted to support the result of the questionnaire analysis by the students and also to get accurate data.

\section{Developed E-Scattergories}

This study is aimed to create a learning media based on the scientific approach steps for the students and also teacher needs. The researcher used E-Scattergories game as media. The media that made by the researcher done in several steps. The step planing consist of preparing the material, designing the layout, and. choosing the background. The game consist of material and questions that students' need.

\section{Validating by Experts}

The media that already being developed were validated by the experts. Questionnaire sheet was used by the expert to measure whether the e-learning media was already appropriate or not.

\section{Revising}

The game was rivised by researcher to get the best result based on the sugggestions and critics given by experts.

\section{Final Product}


After revising the games, the last step was final product. The final product were the final scattergories games of writing descriptive text for the tenth grade at SMK Namira Tech Nusantara Medan.

\section{RESEARCH FINDINGS AND DISCUSSION}

\section{Research Findings}

The research finding shows the necessities of the tenth grade students of SMK Namira Tech Nusantara Medan related to the students' difficulties in mastering language skill. There are four skill that can be use in English such as listening, reading, writing, and speaking. The table above indicates that most of the students have difficulties in mastering speaking skill with $66.7 \%$ and writing skill with percentage $33.3 \%$. There are some problem faced by the difficulties of students in writing English text such as lack of vocabulary, they do not understand about the structure of writing and the example that they learned can't be found in daily life. In this case, the data also shows their opinion about Descriptive Text material. The percentage of students who said that all of them have difficulties in learning descriptive text.

The researcher finds that students' learning source in learning english prefer to choose internet as their learning souce in learning English wherease all of students prefer to use media to stimulate their learning process. It can be seen The number of students who said that using media is the most interestingly and the highest overall percentage among others with $77.8 \%$, Out of a total of 18 students, $100 \%$ said that 
use of E-Scattergories in learning descriptive text will be more interested and make students have many ideas in writing descriptive text.

\section{Discussions}

This study aimed to find out the students' need and develop the media for the tenth grade students of SMK Namira Tech Nusantara Medan. The media developed by the researcher are appropriate and related to the students' interest since it is based on their need analysis. Analyzing the students' need based on their interest is one of the way to improve their learning motivation in writing skill. The findings show that the students need motivation to learn and one of the way is by using the interesting media.

Furthermore, this present study purposes the needs analysis to find out the needs of learners. Then, by this media development, the need of the learners can be fulfilled. Media can be effectively used in a formal situation where students are working independently or the teacher is working with another group of students. Media plays a significant role in the education of students with exceptionalities children with disabilities in particular need special instructional treatment which is supplemented with adaptation and specially designed media for effective instruction of such students. 
At the end, the result of this study suggest the teacher to use the interesting media based on students' needs and interests. As Thomas (2008:106) explains that teacher who uses a variety of teaching aids has successfully converted most classrooms from traditional setup, where teachers do most of the talking and students are passive listeners, into participatory learning centers facilitating productive learning.

\section{CONCLUSIONS AND SUGGESTIONS}

\section{Conclusions}

The existing media used by the teacher was not effective enough to stimulate and encourage the learners to write. They find it is difficult to write and make a descriptive text. They want to have an interesting writing media which motivate them to learn and write the kind of descriptive text. The solution for the students is developing the new interesting writing media. This writing media is based on students' needs and make students more interest in learning as well as ease the students to write through E-Scattergories game follows the R\&D phases by Borg and Gall (2003) which is simplified into, (1) Gathering Data and Information, (2) Need Analysis, (3) Designing Media, (4) Validating by the experts, (5) Revising, (6) Final Product. The score of validation from the validators was $92.6 \%$ and it was categorized as relevant. It means that the media were valid an appropriate to use as learning media for students. 


\section{Suggestions}

In relation to the conclusions above, suggestions were stated for the consideration for the future. For the teacher, teacher should consider students' need in choosing the learning media. The learning process can be successful if the teacher mastered in explaining descriptive text as well as using a learning media that can support the teaching learning process. The teacher can use and develop the learning quality by using E-Scattergories that has been validated by expert in their English class. For the students, they also can practice their descriptive writing by using this media in order to help them in learning English and increas their writing skill. The result of the study can be considered as recommendation for the researchers to make further research related to the study. 


\section{REFERENCES}

Alwasilah, A.C. (2004). Improving Writing Skill through Collaborative Writing.

In B.Y. Cahyono \& U. Widiati. The Tapestry of English Language Teaching and Learning in Indonesia (pg. 99-108). Malang: State University of Malang Press.

Arikunto. (1996). Prosedur Penelitian Suatu Pendekatan Praktik. Jakarta: Rineka Cipta.

Borg, WR and MD. Gall. (2003). Educational Research: an Introduction (7. Ed). New York: Longman Inc.

Considine, D. M. (1995). Are we there yet? An update on the media literacy movement. Education Technology. Vol.35 (4): 32-43.

Constantinescu, R. S. (2012). Learning by playing: Using computer games in teaching English grammar to high school students. Education Source. 110115 .

Crookal, D. (1990). Simulation, gaming, and language learning. Newbury House.

Depdiknas. (2004). Pembelajaran Teks Descriptive. Jakarta: Departemen Pendidikan dan Kebudayaan Dirjen Pendidikan Tinggi.

Ersoz, Aydan. (2000). Six Games for AFL/ESL Classroom. The Internet TESL 
Journal. Vol. VI (6).

Fatimah, S., and Zahara, W. (2018). Using Guessing Game in Teaching Writing Descriptive Texts to Junior High School Students. Jurnal of Language Teaching. Vol. 7 (1): 202-207.

Gerot, L and Wignell, P. (1994). Making Sense of Functional Grammar. Sydney: Gerd Stabler.

Gozcu, E. 7 Caganaga, C. K. (2016). The importance of using games in EFL classrooms. Cypriot Journal of Educational Science. 11(3): 126-135.

Hammer, J. (2004). How to Teach Writing. England: Longman.

Hidayati, Irma. (2015). Improving English Writing Skills Through Board Games for Grade X Students. English Education Departement. Faculty of Languages and Arts. Yogyakarta State University.

Husain, MA. (2017). The Use of Scattergories Game to Improve the Vocabulary Mastery. English Departement. Faculty of Languages and Arts. Semarang State University.

Khikmah, Nur. (2016). The Use of Scattergories Board Game to Improve Students' Vocabulary Mastery and Reading Comprehension. English Education Departement. Teacher Training and Education Faculty. State Institute for Islamic Studies (IAIN) Salatiga.

Lee, W.R. (2000). Language teaching games and contests. Oxford University Press.

McCallum, G. P. (1980). 101 word games: For students of English as a second or foreign language. Oxford University Press.

Mei, Y.Y., \& Yu-jing, J. (2000). Using games in an EFL class for children. Daejin Univeristy ELT Research Paper.

Noprianto, Eko. (2017). Students' Descriptive Text Writing in SFL Perspective. Indonesian Journal of English Language Teaching and Applied Linguistics (IJELTAL). Vol. 2(1): 65-81.

Putri, W., \& Saun S. (2013). Using One Word- Two Word- Three Word Game in 
Teaching Writing a Descriptive Text. Journal of Language Teaching. Vol. 1 (2).

Pradana, S. (2019). Developing Weblog as Effective Media in Teaching Writing. English Education Departement. Faculty of Languages and Arts. Yogyakarta State University

Prensky, M. (2006). Don't Bother Me, Mom --I'm Learning!. St. Paul Minnesota: Paragon House.

Ricardo. (2018). An Approach to Digital Game-based Learning: Video-games Principles and Applications in Foreign Language Learning. Journal of Language Teaching and Research. Vol. 9 (6).

Richards, J.C. (2002). Methodology in Language Teaching:

An Anthology of Current Practice. Cambridge: Cambridge University Press.

Robson, K., Plangger, K., Kietzmann, J. H., McCarthy, I., \& Pitt, L. (2015). Is it all a game? Understanding the principles of gamification. Business Horizons. Vol. 58 (4): 411-420.

Roman, Tamatha. (2010). Fill that gap! Quick Games for All Levels. Monterey Monterey Institute of International Studies.

Sato, A. De Haan, J. (2016). Applying an Experimental Learning Model to the Teaching of Gateway Strategy Board Games. International Journal of Instruction. Vol. 9 (1).

Sigurdardottir, Sigridurdogg. (2010). The Use of Games in the Language Classroom. Iceland: Sigillum Universitatis Islandiae.

Smaldino, D.J., Heinich, R., Molenda, M., \& Russell, J. (2005). International technology and media for learning. New Jersey: Pearson Education.

Stojkovic, M. K., and D. M. Jerotijevic. (2011). Reasons for Using or Avoiding Games in an EFL Classroom. From: http://eca.state.gov/forum/vols/ vol33/no1/p35.html.

Sugiyono. (2009). Metode Penelitian Kuantitatif, Kualitatif dan R\&D. Bandung: Alfabeta.

Talak-Kiryk, Amy. (2010). A Thesis: Using Games in a Foreign Language 
Classroom. Vermont: SIT Graduate Institute.

Wayan, ID. (2016). Genre-Based Approach: What and How to Teach and to Learn Writing. Canadian of Science and Education. Vol. 9 (9).

Werbach, K. (2014). ReDefining Gamification: A Process Approach. In A.

Spagnolli, L. Chittaro, and L. Gamberini (eds.), Persuasive Technology. New York: Springer.

Wulandari, Eka. (2016). Promoting Fun Learning in Writing Through Games.

Journal of English Education, Literature, and Culture. Vol. 1 (2).

Yoandita, PE. (2019). An Analysis of Students' Ability and Difficulties in Writing Descriptive Text. Journal of English Pedagogy, Linguistics, Literature, and Teaching. Vol. 7 (1). 